\title{
Discourses on Zakat and Its Implementation in Contemporary Ghana
}

\author{
Holger Weiss
}

\section{INTRODUCTION}

This chapter explores the recent discourses on zakat or mandatory/ obligatory alms as a tool for poverty alleviation among Muslim scholars in Ghana. This discourse started about two decades ago and is part of their vision for achieving political and economic empowerment of the Muslim population in Ghana. Muslims in Ghana constitute a minority; according to the 2010 census they make up about $18 \%$ of the total population of some 25 million. Although the country has been portrayed as a success in terms of political and economic development, this has been mainly affected the Christian-dominated, affluent and politically influential southern regions where two-third of the population are living. ${ }^{1}$ Muslim communities are predominant in the southern urban economically and socially marginalized so-called Zongo quarters as well as in the

\footnotetext{
${ }^{1}$ World Bank, Ghana-Performance and Learning Review of the Country Partnership Strategy for the Period FY13-FY18 (Washington, DC: World Bank Group, 2016).
}

\section{H. Weiss $(\square)$}

Department of History, Åbo Akademi University, Turku, Finland e-mail: holger.weiss@abo.fi 
northern urban and rural savanna regions. ${ }^{2}$ The "Muslim landscape" in contemporary Ghana constitutes of five major religious sub-spheres or religious sects: the Tijaniyya (Sufi), the Ahlus-Sunnah (Salafi), the Ahmadiyya, the Istiqaama (Ibadiyya) and the Shi'a community. ${ }^{3}$ The two first mentioned are by and large the most influential one and the reflections to be presented in this chapter are based on interviews with Tijani and Salafi scholars. ${ }^{4}$

Although Ghana's economic growth has lifted it to the status of a lower middle-income country, its impact has not affected the lower strata of society and has not translated into productive and decent employment opportunities for a significant section of the population. Ghanaian government investments into social welfare and economic development

${ }^{2}$ Holger Weiss, Begging and Almsgiving in Ghana: Muslim Positions Towards Poverty and Distress (Uppsala: Nordiska Afrikainstitutet, 2007).

${ }^{3}$ Holger Weiss, Between Accommodation and Revivalism: Muslims, the State and Society in Ghana from the Precolonial to the Postcolonial Era (Helsinki: Finnish Oriental Society, 2008); Yunus Dumbe, Islamic Revivalism in Contemporary Ghana (Huddinge: Södertörn University, 2013); Abdulai Iddrisu, Contesting Islam in Africa. Homegrown Wabhabism and Muslim Identity in Northern Ghana, 1920-2010 (Durham, NC: Carolina Academic Press, 2013); Ousman Murzik Kobo, "Shifting Trajectories of Salafi/AhlSunna Reformism in Ghana," Islamic Africa 6, no. 1-2 (2015): 60-81; K.A. Balogun and A.A. Abdussalam, "Arguments and Counter-Arguments: A Critical Analysis of the Ahlus-Sunnah and Tijâniyyah Brotherhood Dispute in Ghana," International Journal of Humanities and Social Science Invention 4, no. 3 (2015): 1-11; Yunus Dumbe, "Islamic Polarisation and the Politics of Exclusion in Ghana: Tijaniyya and Salafist Struggles over Muslim Orthodoxy," Islamic Africa 10 (2019): 153-180. On the Ahmadiyya, see further John H. Hanson, The Ahmadiyya in the Gold Coast: Muslim Cosmopolitans in the British Empire (Bloomington: Indiana University Press, 2017); on the Istiqaama, see further Mahmud Mukhtar Muhammed and Umar Wahab Sina, "Faith in National Development: A Review of the Activities of the Istiqaama Muslim Organisation of Ghana." Paper presented at 3rd International Conference on Religion and National Development 6th-7th September 2018, Department of Religious Studies, Kwame Nkrumah University of Science and Technology (KNUST), Ghana; on the Shi'a, see further Dumbe, Islamic Revivalism, and Ousman Murzik Kobo, "Islamic Institutions of Higher learning in Ghana: The Case of the Islamic University College," in Muslim Institutions of Higher Education in Postcolonial Africa, eds. Mbaye Lo and Muhammed Haron (New York: Palgrave Macmillan, 2016): 179-191.

${ }^{4}$ The author has conducted fieldwork in southern and northern Ghana since 2017. The research project Muslim Empowerment in Ghana (MEG) is funded by the Finnish Society for Sciences and Letters (2017-2018) and the Academy of Finland (2019-2021), and builds on the authors previous research project on zakat in Ghana, running from 1999 to 2006 . 
projects have for decades been concentrated to the southern and politically dominant part of the country. Only in 2017, the government earmarked budgetary funds for deprived urban areas and established the Ministry of Inner Cities and Zongo Development. Not surprisingly, national and international civil philanthropy organizations have played an important role in supporting the implementation of the Millennium Development Goals. According to United Nations Development Programme Sustainable Development Goals Philanthropy Platform, non-governmental foundations invested USD394.2 million to support various programmes under the Millennium Development Goals in Ghana during 2002-2012. Impressive as it is, the sum is a small proportion of Official Development Aid that the Ghanaian government received during the same period, namely USD3.6 billion. ${ }^{5}$

Muslim faith-based NGOs constitute a small fraction in the Ghanaian landscape of philanthropy. As elsewhere in sub-Saharan Africa, this landscape is changing and leaning towards an institutionalization of giving. While Christian faith-based NGOs have dominated the Ghanaian landscape of philanthropy since independence in 1957, institutionalized and vertical Muslim faith-based NGOs are a relatively recent phenomena and in general invisible for non-Muslims. ${ }^{6}$ Despite the success of some individual Muslims to gain economic and political influential positions in Ghanaian civil society, some of them have even emerged as Muslim High Net-Worth Individuals, the majority of the Muslim population in Ghana constitute an economically and politically marginalized minority. ${ }^{7}$ Traditionally, various forms of horizontal philanthropy constituted the basic form of support within the Muslim community. Zakat was a private matter, too: Informal, individual and person-to-person. At times, the

${ }^{5}$ Enabling Environment of Philanthropy in Ghana (Accra: SDG Philanthropy Platform, United Nations Development Programme, 2017), 23.

${ }^{6}$ Enabling Environment of Philanthropy in Ghana, 27-28; Emmanuel Kumi, "Diversify or Die? The Response of Ghanaian Non-Governmental Development Organisations (NGDOs) to a Chaning Aid Landscape," PhD thesis, University of Bath, 2017.

${ }^{7}$ Weiss, Begging and Almsgiving in Ghana; David E. Skinner, "Da'wa and Politics in West Africa: Muslim Jama'at and Non-Governmental Organisations in Ghana, Sierra Leone and The Gambia," in Development and Politics from Below: Exploring Religious Spaces in the African State, eds. Barbara Bompai and Maria Frahm-Arp (London: Palgrave MacMillan, 2010), 99-130. 
imam was consulted but no mosque or zakat funds existed. ${ }^{8}$ In addition, the sums that were doled out to beggars and poor people were usually small tokens, keeping the recipient alive for a day but hardly changed their life. Therefore, zakat was neither a tool for the eradication of poverty nor an instrument for the empowerment of Muslims and had never been so in twentieth-century Ghana. This, at least, was the conclusion most Muslim scholars made when I interviewed them on the issue about 15-20 years ago. ${ }^{9}$

Instead, what existed in terms of formal forms of vertical philanthropy directed towards the Muslim community in Ghana were various local, national and trans/international Muslim faith-based organizations. Stating from the early 1990s, Muslim faith-based NGOs such as the Islamic Council for Development and Humanitarian Services (ICODEHS, established in 1991) started to advocate "development", "democracy" or even "individual rights", goals and objectives, which they sometimes signal in their names. Many of them are actively attempting to gain access to funds from overseas, mostly from OIC member countries and international/transnational Muslim faith-based NGOs, for mosque, health clinics and school construction projects as well as educational activities. ${ }^{10}$

However, there were indications on a different discourse on zakat already during my previous research. The core idea of this discourse is the utilization of zakat for poverty eradication and the empowerment of the Muslim community by institutionalizing its collection and distribution. ${ }^{11}$ Several initiatives have been launched since then, resulting in vertical and institutionalized philanthropy operated by various national Muslim faithbased NGOs. In 2008, some Muslim leaders and organizations established the National Zakat House. Three years later, Muslim politicians and government officials opened the Zakat and Sadaqa Trust Fund of

\footnotetext{
${ }^{8}$ Holger Weiss, "Reorganising Social Welfare Among Muslims-Islamic Voluntarism and Other Forms of Communal Support in Northern Ghana," Journal of Religion in Africa 32, no. 1 (2002): 83-109.

${ }^{9}$ Weiss, Begging and Almsgiving in Ghana. See also Emmanuel Kumi, "Aid reduction and NDGOs' Quest for Sustainability in Ghana: Can Philanthropic Institutions Serve as Alternative Resource Mobilisation Routes?” Voluntas 30 (2019): 1443.

${ }^{10}$ Weiss, Begging and Almsgiving in Ghana.

${ }^{11}$ Rabiatu Ammah, "Islam and Poverty Reduction Strategies in the Ghanaian Muslim Community," Ghana Bulletin of Theology 2 (2007): 3-20.
} 
Ghana. How are these initiatives functioning? What are their objectives and societal impacts? What are their links to transnational/international Muslim Faith-Based Organizations? Last, but not least, how should zakat funds be defined in a secular state-are they registered bodies, associations or non-governmental organizations or non-registered, unofficial units run by local communities? Since 2017, I have been collecting information about these initiatives by conducting interviews with imams and scholars in Accra, Kumasi, Ejura and Tamale. In addition, I have consulted internet sources, such as homepages and Facebook accounts, as well as online and paper versions of newspapers.

\section{Muslim Scholars and the Call to Eradicate Poverty}

In 2016, the National Imam of the Ahlus-Sunna Haji Umar Ibrahim Imam called on Muslims in Ghana to declare war on "the enemies to human development", most notably hunger, ignorance, diseases, conflicts and wars. He further urged Muslim chiefs, imams and the wealthy to consider the establishment of educational and health facilities as remedies for battling ignorance and disease. Attacking traditional Muslim education, he identified modern secular education as the prime factor to overcome the marginalization of Muslims. ${ }^{12}$ In an interview one year later, he criticized the Ghanaian Muslim community to depending on economic assistance and investments from Arab governments and philanthropists and declared that "until we stand up to provide for ourselves, no foreigner can provide and build our community to the expected standard we desire". 13

Sheikh Amin Bamba, in turn, at the launching of a collaborative community development programme of the UNFPA and the Bamba Islamic Institute Ghana (BII-Ghana) in 2017, critically noted that the high rate of illiteracy was the main reason for blocking the empowerment of Muslims in Ghana. In his mind, "illiteracy has denied and continues

${ }^{12}$ Alhassan M. Baidoo, "Muslims to Declare War on Their Enemies-Haj Umar of ASWAJ," http://www.mytawheedonline.com/2016/05/11/muslims-to-declare-war-ontheir-enemies-haj-umar-of-aswaj-2/(checked 16 November 2017).

${ }^{13}$ Abdul-Rahim Naa Abdul-Lahie, "A Chat with Hajj Umar Ibrahim, National Imam of Ahlul Sunna Wal Jama's (ASWAJ),” Today's Muslim, 16 October 2017, http://thetodaysmuslim.com/discussions/a-chat-with-hajj-umar-ibrahim-national-imam-of-ahlul-sunna-wal-jamaa-aswaj/ (checked 20 May 2019). 
to deny majority of our people critical information that they require to make informed economic, social and political decisions to improve their livelihood and general wellbeing", and urged Muslim leaders and organizations to cooperate with relevant government and non-governmental agencies for the development of Muslim communities and the promotion of the UN Sustainable Development Goals. ${ }^{14}$

Similar conclusions were reached by Anika Altaf in her Participatory Assessment of Development (PADEV) project of interventions by local and national Muslim faith-based NGOs in the Northern Region. Most of her informants mentioned only few Islamic interventions, the bulk of them being mosques and madrasas. Although the recipients generally regarded "Islamic aid", i.e. coming from international or national Muslim faith-based NGOs and Muslim philanthropists, as more than welcomed, it was still criticized to be generally limited to fund religious activities. Nevertheless, Altaf identifies the lack of own funding to be the biggest constrain for local and national Muslim faith-based NGOs in the implementation of social and economic development projects. On the other hand, the capacity for generating funding in Ghana is minimal; the only organization being self-sufficient is the Ahmadiyya Muslim Mission. Interestingly, Altaf concludes her analysis by underlining the need for Ghanaian Muslim faith-based NGOs to start to explore ways to be either fully or partly self-sufficient, among others through an institutionalized collection of zakat. ${ }^{15}$

The need for a reorientation in the approach of the Muslim communities in Ghana towards poverty alleviation in accordance with the UN goals of sustainable development of the Agenda 2030 was further highlighted by the National Chief Imam at the 55th Session of the Commission on Civil Society at the United Nations in February 2017. In his speech, National Chief Imam Dr. Osman Nuhu Sharubutu made a plea for an Islamic perspective on eradicating poverty. Following a

\footnotetext{
${ }^{14}$ Savannah News, "Illiteracy Is the Bane of Muslims' Development-Sheikh Bamba," 16 May 2017, http://savannahnewsblogspotcom.blogspot.com/2017/05/illiteracy-is-bane-of-muslims.html (checked 19 May 2019); "UNFPA Partners Bamba Institute to Promote SDGs," GhanaWeb, 16 May 2017, https://www.ghanaweb.com/GhanaHomePage/NewsArchive/ UNFPA-partners-Bamba-Institute-to-promote-SDGs-538205 (checked 19 May 2019).

${ }^{15}$ Anika Altaf, Perceptions and Reflections of Islamic Development Initiatives in Northern Ghana (Amsterdam: PADEV, 2010), http://dare.uva.nl (checked 2 November 2017).
} 
classical interpretation of the Third Pillar of Islam, the National Chief Imam underlined the imperative for Muslims to be charitable and to provide for the needy and concluded that zakat is the means for economic relief and poverty eradication. The Ghanaian government, he thankfully noted, had opened a new approach towards the economic and social development of underprivileged urban low-income settlements known as the Zongo communities by establishing the Ministry of Inner Cities and Zongo Development in 2017. However, he also stressed that "for poverty to be completely eradicated, a new approach must be adopted in consultation with the religious leaders and clergy". In his mind, this new approach should strive to create employment and means of distributing national resources equitably for the benefit of all as well as to focus on the poor by creating a basket for their needs and wants and enable their vocational training. Most of all, Osman Nuhu Sharutubu stressed the need to develop new mechanisms of reaching out to the wealthy and resourced people in the Muslim community to do more in charity. ${ }^{16}$

\section{Horizontal, Informal Philanthropy and the Traditional Discourse on Almsgiving}

The traditional discourse is articulated by imams in their sermons and preaches during the Friday prayers, highlighting and reminding Muslims of their moral obligation to pay zakat and to alleviate the sufferings of their poor neighbours. This discourse is rooted in the traditional interpretation of zakat as a collective obligation incumbent upon every Muslim. Although zakat is discussed in public in the mosques, the collection and distribution of zakat remain largely a private affair. The traditional way of collecting and distributing zakat in Ghana is conducted locally and is not institutionalized. ${ }^{17}$ Some wealthy Muslims give their

\footnotetext{
16 "National Chief Imam's Speech at UNESCO," http://www.tijjaniyamuslims.org/ news/?news_id=15893bbf73a9a4\&pn=3 (checked 10 November 2017). The speech was read by the Personal Assistant to the National Chief Imam Alhaji Khuzaima Mohammed Osman.

${ }^{17}$ Interview with Ashanti Regional Chief Imam Sheikh Abdul Mumin Haruna, Kumasi, 15 September 2018; written response to questionnaire; handed to Sheikh Abdul-Razaq, Nurul Islam, Kumasi, 16 September 2018; written answer, transcribed by Yunus Dumbe, 20 September 2018, received 21 September 2018; interview with Sheikh Abdurrahman, founder and president of Ansar Addeen, and Sheikh Abdallah, General Secretary of Ansar Addeen, Kumasi, 7 September 2019.
} 
alms to various recipients, others donate it to specific recipients such as widows, orphans or mosques. In general, zakat is donated in cash or in kind, including cloths and textiles, sandals, shoes and food items. ${ }^{18}$ In general, however, the mosques would not have a specific bayt al-mal or fund for zakat. ${ }^{19}$

The traditional discourse dominates during Ramadan (fasting month) when almsgiving and sharing is at the centre of the sermons and culminates during the Eid al-Fitr festival with the collection of zakat al-fitr and the donation of food items to poor and needy Muslims. While the sermons as well as the giving of charity and sharing of food with one's poor and needy neighbour constitutes an integral part of the Muslim sphere, the articulation of the traditional discourse in public in the printed media, and more recently in the social media, too, is a relatively new phenomenon in Ghana. Starting during the 1990s when two Muslim religious festivals, Eid al-Fitr and Eid al-Adha, where declared national public holidays, the newspapers started to publish articles on Islamic faith and everyday life of Muslims in Ghana. Newspapers and social media notify the beginning of the two Muslim religious festivals by publishing the season's greetings of the state authorities to the Muslim community. ${ }^{20}$

Traditional community-centred and privately given zakat cannot be enforced or controlled by the imams or the mosque community and therefore lacks an institutional framework or organization. Most mosques and communities do not collect zakat at all and most of the affluent Muslims and businessmen do not give their zakat to the imams. The main reason for this is due to lack of trust and ignorance, many scholars critically commented to me. ${ }^{21}$ "You need to give one thousand cedis to a poor, not five or twenty", Mallam Aminu Bamba critically

${ }^{18}$ Interview with Muhammed Al-Mahaman, HOD Arabic and Islamic Studies of Al-Faruq College of Education, Wenchi, Brong Ahafo, and advisor at Sakafiya mosque, Kumasi, 15 September 2019.

${ }^{19}$ Interview with Sheikh Abdulsalam Ahmed, Regional Chief Imam Northern Region, Tamale, 10 April 2019; interview with Sheikh Dr. Tamim, General Secretary of the Anbariya Sunni Community, Tamale, 9 April 2019.

${ }^{20}$ Weiss, Between Accommodation and Revivalism.

${ }^{21}$ Interview with Mallam Aminu Bamba, Ejura, 4 April 2019; interview with Sheikh Abdurrahman, founder and president of Ansar Addeen, and Sheikh Abdallah, General Secretary of Ansar Addeen, Kumasi, 7 April 2019; interview with Sheikh Issah, Islamic Education Unit Manager, Tamale, 9 April 2019. 
commented the habit of doling out small sums as alms to beggars and needy persons after the Friday prayers. ${ }^{22}$ Other scholars, such as Sheikh Saeed Abubakar Zakaria, even claim that such piecemeal distribution of the alms is not zakat at all and cannot be regarded as fulfilment of zakat. ${ }^{23}$

Although zakat is mandatory, neither the imams not the mosque communities have any means at their disposal to enforce its collection. ${ }^{24}$ Also, it is upon the giver to decide upon the amount to be given as zakat and weather it is paid in cash or in kind. Local scholars and imams, in their turn, remind their community members of the nisab (threshold) of $2.5 \%$ of wealth accumulated during one year as the part to be paid as zakat. ${ }^{25}$ Until recent decades, the stipulation of the annual nisab was done locally by the individual imams which resulted in conflicts among scholars of the minimum amount to be paid. Consequently, there existed a wide variation of local patterns and ways of handling the collection of zakat in the Muslim communities throughout Ghana and, in most case, it remained a private rather than a public affair and little, if anything, is known about its impact. ${ }^{26}$

The core argument of the traditionalist discourse on zakat highlights the private act of pious Muslims. Wealthy Muslims might consult an imam for the calculating the nisab or identifying needy recipients of their alms but would rarely channel their zakat via the imams or mosques. Instead, they prefer to distribute their alms-zakat as well as sadaqa-directly to individual poor persons. This private distribution of alms usually takes places after the Friday prayers and takes the form of smaller sums distributed directly to specially targeted individuals as a kind of patron-client relationship or as tokens haphazardly given to any beggar in the street. However, the giving of zakat as a private pious is a

${ }^{22}$ Interview with Mallam Aminu Bamba, Ejura, 4 April 2019.

${ }^{23}$ Interview with Sheikh Saeed Abubakar Zakaria, head of the Anbariya Sunni Community, Tamale, 9 April 2019.

${ }^{24}$ Interview with Sheikh Dr. Ismail Saeed Adam, Regional Chief Imam of ASWAJ Ashanti Region, Kumasi, 5 April 2019.

${ }^{25}$ Interview with Sheikh Abdul Wadud, Zameen (President) of the Tijjaniya Muslims Movement of Ghana, Kumasi, 5 April 2019; interview with Sheikh Abdurrahman, founder and president of Ansar Addeen, and Sheikh Abdallah, General Secretary of Ansar Addeen, Kumasi, 7 April 2019.

${ }^{26}$ Interview with Sheikh Abdurrahman, founder and president of Ansar Addeen, and Sheikh Abdallah, General Secretary of Ansar Addeen, Kumasi, 7 April 2019. 
double-edged sword. Although the recipient might receive just enough money survive for one day, the sums thus received make no impact on the life of a poor person and are insufficient to raise him or her up from poverty. Even worse, private Muslim charity has generated a negative public image in Ghana as begging and private almsgiving is largely connected with the Muslim community. ${ }^{27}$

\section{Towards Vertical Philanthropy: The Instrumentalist Discourse}

The second discourse has its roots in the critical reflections of Muslim scholars on the semiprivate/public communal way of collecting and distributing zakat. Both the imams and the scholars identify poverty as the main cause for the marginalization of Muslims in Ghana. In contrast to the traditional discourse on zakat which highlights the moral obligation to alleviate the sufferings of the poor and needy, the instrumentalist discourse highlights the potentials of zakat as an Islamic instrument for poverty alleviation. This discourse started to take root in Ghana about two decades ago. In October 2004, the Dawah Academy organized the two-day seminar on the role of Islam in poverty reduction and wealth creation in Tamale which, perhaps, was among the first attempts to articulate a change in the collection and distribution of zakat. The novelty of that seminar was its focus on the idea to raise funds for community development through the regular payment of zakat. ${ }^{28}$ Fifteen years later, the discussions on the payment of zakat are not only conducted among Muslim scholars and highlighted by imams in their sermons during Ramadan but are also addressed by Muslim commentators on social media. For example, in February 2019, the internet platform Zongo Republic asked its Muslim readers whether they had paid their zakat on value-added wealth and sarcastically declared: "Menzgold customers, have you paid your zakat?"29

${ }^{27}$ Weiss, Begging and Almsgiving.

${ }^{28}$ GNA, "Muslims Attends Seminar on Zakāt," http://ghanaweb.com/GhanaHomePage/ regional/artikel.php? ID $=67225$ (checked 16 November 2012).

29 “So, Did Muslim Menzgold Customers Pay Zakat?," Zongo Republic, 22 February 2019, https://zongorepublic.com/so-did-muslim-menzgold-customers-pay-zakat/ (checked 23 April 2019). 
The instrumentalist discourse is fuelled both by indigenous and by foreign participants. In 2012, the online-platform Modern Ghana published the Ramadan message by the Nigerian author and journalist Muhammad Ajah. Although his text addressed Muslims in Nigeria, his call to establish "a mini Baitul-Zakah's to regulate the zakat or donations from local and international donors" raises the question, if his idea also could inspire discussion in Ghana. ${ }^{30}$ In 2013, Haji Adams Goldwater raised a similar plea in his Ramadan message in Tamale and called for the transformation of the mosques from being space for ritual worship to institution for social reforms, education and wealth creation. His core urge was the establishment of an "Education Endowment/Zakat Fund" to gather resources to support brilliant but needy students as well as a "Business Development Fund" to aid persons with achievable business plans to set up enterprises that can be avenues of employment for the youth. ${ }^{31}$ However, he did not specify if he envisioned the establishment of one national or several regional funds.

Haji Adams Goldwater's plea was one among several of Muslim scholars to invest in education projects for Muslim youths. Already in 2004 had Yusif Adam Nanyama, Executive Director of the Centre for Islamic Development and Propagation (CIDA), appealed to Islamic NGOs to channel $70 \%$ of their resources into the development of the education of Muslim students. ${ }^{32}$ Initially, however, there was no obvious link between the instrumentalist discourse on zakat and the calls for investing in Muslim education projects although the vision of investing zakat in promoting modern education for Muslim children was already articulated at the 2004 meeting of the Dawah Academy in Tamale. However, before these visions materialized in the institutionalization of zakat in the early 2010s, National Chief Imam Sheikh Dr. Osman Nuhu Sharubutu opened a new chapter in the discourse on empowerment of Muslims

\footnotetext{
${ }^{30}$ Muhammad Ajah, "Ramadan: A Muslim's Month of Vigilance and Plans for Future by Muhammad Ajah," Modern Ghana, 17 April 2012, https://www.modernghana.com/ news $/ 406360 /$ ramadan-a-muslims-month-of-vigilance-and-plans-for-future.html, see also http://www.newsghana.com.gh/ramadan-a-muslims-month-of-vigilance-and-plans-for-future-by-muhammad-ajah (checked 21 February 2019).

${ }^{31}$ Adams Goldwater, "Ramadan in Tamale," 9 July 2013, https://www.ghanaweb.com/ GhanaHomePage/features/Ramadan-In-Tamale-278977 (checked 25 February 2019).

32 "Invest in Secular Education-Islamic NGOs Told," Modern Ghana 9 November 2004, https://www.modernghana.com/news/66283/invest-in-secular-education-islamicngos-told.html (checked 25 February 2019).
} 
in Ghana by launching his education trust, the Dr. Sheikh Osman Nuhu Sharubutu Education (SONSETFUND), in 2009. The Fund is a registered non-governmental organization and is led by a thirteen-member executive council with a four members secretariat located at the National Chief Imam's residence in Fadama, Accra. The chairman of SONSETFUND is the Muslim philanthropist Sheikh Mustapha Ibrahim whereas Alhaji Khuzaima Mohammed Osman serves as General Secretary. SONSETFUND is not a zakat institution although it direct its calls for support and donations to Muslims in Ghana. However, the sources of its funding are not known apart from that the Fund has received donations and financial support from some Ghanaian business enterprises and national Muslim organizations as well as international donor agencies, such as the Turkish International Development Corporation (TIKA). ${ }^{33}$

A few years later, a similar initiative was launched by the Coalition of Muslim Organisations-Ghana (COMOG). In 2013, the organization organized in collaboration with the Turkish NGO Human Associations International (HUDAI) a one day's Ramadan Iftar Forum. HUDAI had a few years earlier started its operations in Ghana and had awarded over 100 scholarships to Ghanaian students of science and technology to study in Turkey. As a result, COMOG agreed to establish a National Muslim Education Trust in collaboration with other major Muslim groupings in the country. In its initial phase, the source for funding of the project would be through voluntary donations. ${ }^{34}$ Nevertheless, COMOG's Education Trust never took off. Donations were scarce and soon the project was shelved. Instead, a new education project, the Baraka Initiative, was launched by some younger members of COMOG in 2017 and gathered funding through donations from the Lebanese community in Accra. ${ }^{35}$

\footnotetext{
${ }^{33}$ Interview with Alhaji Khuzaima Mohammed Osman, General Secretary of SONSETFUND, 6 December 2017. A list of donors and contributors to SONSETFUND was published on the old homepage in 2012 and listed 37 organizations and individuals (9 March 2012, http://sonsetfund.org/newsevents?news_id=14f5bfcc2ee739, checked 16 November 2012); however, this information is not available on the new homepage.

34 "Muslim Coalition Initiate Establishment of Education Fund," GNA, 31 July 2013, http://edition.myjoyonline.com/pages/news/201307/110459.php (checked 12 March 2014).

${ }^{35}$ Interview with Haji Mumuni Sulemana, 12 September 2018.
} 


\section{The Institutionalist Discourse: ZaKat AND Vertical Philanthropy}

The traditional and the instrumental discourse on zakat in Ghana has hitherto only in general terms addressed the reorganization of the collection and distribution of zakat in Ghana. The basic argument highlighted in these discourses is the claim that most Muslims are poor and prefer to pay zakat in the traditional way. Also, there is a hidden, sometimes even outspoken critique about the way zakat is doled out-seemingly haphazard and without a clear objective to change the life of the poor and needy. Muslim scholars are frank in their critique-at least when interviewed for their opinion on the potentials of the obligatory alms in the eradication of poverty. Doling out zakat in small portions to individual beggars will keep a poor or needy person a live for a day or a week but will not lift him or her up from poverty. Muslim scholars and philanthropists have time and again called for the establishment of institutions that would supervise the collection and distribution of zakat on either a regional or even a national level. ${ }^{36}$ Nevertheless, as Sheikh Amin Bamba in Tamale critically notes, the loose organization of Muslims in Ghana as well as the lack of coordination and trust affect the collection and distribution of zakat. As for now, he points out, zakat has had no impact on the empowerment of Muslims. ${ }^{37}$

By and large, the institutional discourse on zakat started about two decades ago in Ghana. Already in 2003, the National Chief Imam Sheikh Osman Nuhu Sharubutu put the question of establishing a national zakat fund on the agenda of the National Ramadan Conference. However, the then established National Islamic Trust Fund was slow to develop and was shelved a few years later. $^{38}$ In 2005, the National Imam of the Ahlus-Sunna, Sheikh Umar Ibrahim Imam, launched a new initiative, the Bait ul-zakat Fund. However, although the project was initially successful in collecting zakat to a common fund and investing the collected money in a company that bottled drinking water in plastic bags, it soon runs into troubles and disintegrated a few years later. ${ }^{39}$

\footnotetext{
${ }^{36}$ Weiss, Begging and Almsgiving in Ghana.

${ }^{37}$ Interview with Sheikh Amin Bamba Imam, Tamale, 10 April 2019.

${ }^{38}$ Weiss, Begging and Almsgiving in Ghana, 146.

${ }^{39}$ Weiss, Begging and Almsgiving in Ghana, 142-143; Interview with Sheikh Umar Ibrahim Imam in February 2017.
} 
In 2005, too, Alhaji Amen Bonsu, then Second Deputy National Imam of the Ghana Muslim Mission, called on Muslim organizations and individuals to contribute to-an unspecified-zakat fund ${ }^{40}$; it is unclear if he referred to the (then dormant) National Islamic Trust Fund, an existing fund of the Ghana Muslim Mission or an institution yet to be established.

By 2007, none of the above initiatives existed anymore as is demonstrated by the urge of Sheikh Seidu Adam, then Chief Imam of the Ghana Armed Forces, to establish a central Zakat Fund. His vision was a central national institution that received zakat from district, regional and national levels for the implementation of the fund, "so that at the end of every year, the Muslim community would know where to put the zakat to". Not surprisingly, the institutional approach of Sheikh Seidu Adam criticized by one of his commentators for being bureaucratic and inflexible and open for embezzlement by those in charge of the fund. "I will advise that the tithe or zakat be kept in mosque treasurers so that they can use the money to take care of the poor who worship with them and pay [their] utility bills". ${ }^{41}$ One year later, the United Nations Population Fund (UNFPA) organized a conference for 40 Muslim and Christian leaders across Africa in Sokoto, Nigeria. The conference resulted in a joint communiqué which urged Muslims to establish zakat funds in their countries to mobilize resources to support UNFPA to reduce maternal mortality and poverty alleviation. In Ghana, the discussion was taken up by COMOG at a national Zakat Conference in April 2010. The discussions resulted in the launching of a national initiative, the National Zakat House, in September $2011 . .^{42}$

The National Zakat House was a joint project of the Ahlus-Sunna, the Shia and the Tijaniyya leadership in collaboration with the UNFPA, the COMOG, the National Development Planning Commission and the Ministry of Women and Children's Affairs. In addition, it had the

\footnotetext{
40 "Muslims Asked to Contribute to 'Zakat' Fund," GNA, 24 April 2005, http:/ /ghanaweb. com/GhanaHomePage/regional/artikel.php?ID=79978 (checked 25 February 2019).

41 "Muslims Asked to Pay Tithe," GNA, 19 December 2007, http://www.ghanaweb.com/ GhanaHomePage/NewsArchive/artikel.php?ID=136292 (checked 25 February 2019).

42 "UNFPA, Muslim Leaders to Launch National Zakat House Project," GNA, 9 September 2011, https://www.ghanabusinessnews.com/2011/09/09/unfpa-muslim-leaders-to-launchnational-zakāt-house-project/ (checked 21 January 2016).
} 
backing of the National Chief Imam. The National Zakat House was projected to be a centralized point for the collection, management and disbursement of zakat. According to Major Alhaji Mohammed Easah (retired), the then National President of the COMOG, the National Zakat House was a project of a national consensus reached by representatives of Muslims of all major nominations from all the ten regions after a long period of dialogue, discussion, sharing and exchange of views and ideas. Initially, the National Zakat House was run by a 13-member board of trustees under the chairmanship of Ibrahim Mohammad Awal, former Managing Director of Graphic Communications Group Limited. Its main objective was to mobilize resources from Muslim entrepreneurs, scholars and women leaders and fashion out strategies to support activities such as reducing maternal mortality, women empowerment and poverty alleviation among the vulnerable in the Muslim communities. ${ }^{43}$ In addition, echoing the discovery of large sweet crude oil reserves in 2007, the National Zakat House outlined to especially earmark support for Muslim students to undertake studies in petro-chemical engineering. ${ }^{44}$

The public announcement of the intention to launch the project was followed by-silence. In fact, it turned out that the National Zakat House was shelved and never materialized due to lack of commitment of the involved stakeholders. However, this was not a backslash to the institutional discourse on zakat. Several other initiatives were launched, such as the Zakat and Sadaqa Trust Fund of the Muslim Caucus as well as the regional zakat funds of the Ghana Muslim Mission and the ASWAJ.

\section{The Zakat and Sadaqa Trust Fund}

The first successful attempt to establish an institution for the collection and distribution of zakat in Ghana occurred in September 2010 when the Muslim Caucus in Parliament launched its Zakat and Sadaqa Trust Fund, also known as the Zakat and Sadaqa Foundation. According to its mission statement, the general purpose of the initiative was to fight

43 “Muslim Community Praised for Launching National Zakat House Policy," GNA, 20 November 2011, http://www.ghanaweb.com (checked 12 March 2014).

44 "Muslim Journalists Urged to Collaborate to Propagate the Teachings of Islam," Modern Ghana, 5 August 2011, http://www.modernghana.com/print/343699/1/muslim-journalists-urged-to-collaborate-to-propaga.html (checked 25 February 2019). 
poverty, disease and deprivation among Muslim and non-Muslims in the country. The aim of the Trust Fund was to offer scholarships to students in financial crisis "in order to eradicate ignorance and, thereby, eradicate poverty". 45

The initiative was at first presented as an embryo for a national zakat fund. However, the Zakat and Sadaqa Trust Fund has so far remained a foundation supported by Muslim MPs and state employees. According to Dr. Ahmed Yakubu Alhassan, the Spokesperson of the Muslim Caucus in Parliament, the membership of the Trust Fund had grown from 54 to 250 [in 2013] while the fund had grown from GHS12,000 in 2010 to GHS100,000 in 2013. ${ }^{46}$ In 2016, the Zakat and Sadaqa Trust Fund opened a branch office Tamale, two years later it opened its third office in Takoradi. ${ }^{47}$ In 2018, it joined the World Zakat Forum. ${ }^{48}$

There have been several attempts to broaden the community of donors of the Zakat and Sadaqa Trust Fund but so far with little success. In 2016, President John Dramani Mahama proposed to charge 1\% of the total charge on hajj on every pilgrim and transfer the proceeds to the Trust Fund. Although his proposal was met with sarcasm if not outright rejection on social media, some commentators applauded it as a "brilliant idea". ${ }^{49}$ In the same year, the Trust Fund registered on the social media

45 "Muslim Caucus in Parliament Launches Zakat and Sadaqa Fund," GNA, 7 September 2010, http://www.ghanaweb.com/GhanaHomePage/NewsArchive/Muslim-Caucus-inParliament-launches-Zakat-and-Sadaqa-Fund-189934 (checked 21 January 2016).

${ }^{46}$ Musah Yahaya Jafuru, "Key Muslim Bodies to Serve on Hajj Committee," Daily Graphic, 16 July 2013, http://graphic.com.gh/archive/General-News/ (checked 12 March 2014).

47 "Zakāt and Sadaqa Trust Fund Launched in Tamale," Zaa Radio, 26 January 2016, http://zaaradio.com/society/zakāt-sadaqa-trust-fund-launched-in-tamale/ (checked 7 November 2017); https://www.facebook.com/ZakātandSadaqafundGhana/photos/a. 2002861529962781/2149178201997779/?type=3\&theater (checked 14 May 2019).

48 "Secretary-General Addressed at the 7th WZF International Conference in Malacca," https://developing8.org/news/secretary-general-addressed-at-the-7th-wzf-international-conference-in-malacca/ (checked 31 December 2019).

49 "Charge 1\% of Cost of Hajj into Zakāt Fund-Mahama Proposes to Muslims," 26 June 2016, https://www.ghanaweb.com/GhanaHomePage/NewsArchive/Charge-1of-cost-of-Hajj-into-Zakāt-Fund-Mahama-proposes-to-Muslims-450727 (checked 21 February 2019); "Snooping in Hajj Affairs Won’t Sway Muslim Voters," 16 July 2016, https://www.newsghana.com.gh/snooping-in-hajj-affairs-wont-sway-muslim-voters / (checked 14 May 2019). 
platform Fund Raising Global for a campaign to raise zakat and sadaqa with relatively modest results-74 persons donated some GHS1300 as zakat and 33 persons donated about GHS740 as sadaqa. ${ }^{50}$ On the other hand, the Facebook account of the Trust Fund has over 3000 followers (31 December 2019).

The Zakat and Sadaqa Trust Fund manages four schemes. The scholarship scheme provides grants to needy Muslim students to enter tertiary institutions in Ghana while the technical and vocational scheme aims at economic empowerment of beneficiaries through raising their skills. ${ }^{51}$ In 2015, the Zakat and Sadaqa Trust Fund joined the Students Loan Trust Fund (SLTF), a government body under the Ministry of Education, as partner and guarantor for Muslim students. ${ }^{52}$ In 2018, circa GHS70,200 were distributed to support the education of needy students and 36 student loan were guaranteed. Still, the limited resources restrict the outreach of the Zakat and Sadaqa Trust Fund-in 2018, the Trust Fund received 500 bursary applications but could not cover them all. On the other hand, speaking at the 9th Annual Night of Power organized by the Muslim Caucus during Ramadan 2019, VicePresident Dr. Mahamudu Bawumia urged the management of the Zakat and Sadaqa Trust Fund to increase their investments in education. ${ }^{53}$ The medical support scheme is designed to give financial support to defray medical bills, a total of five poor persons have benefitted from the scheme. The Economic Empowerment Scheme is aimed at assisting the deprived within the Muslim community "in order to re-establish their

${ }^{50}$ See https://www.fundraisingafrica.com/DetailView/344 as well as https://www. fundraisingafrica.com/DetailView/343 (checked 19 May 2019).

${ }^{51}$ Musah Yahaya Jafuru, "Key Muslim Bodies to Serve on Hajj Committee," Daily Graphic, 16 July 2013, http://graphic.com.gh/archive/General-News/ (checked 12 March 2014).

${ }^{52}$ Emmanuel Amoquandoh, "Partnership Between SLTF and ZSTF Launched," 11 October 2015, https://www.ghanaweb.com/GhanaHomePage/regional/Partnershipbetween-SLTF-and-ZSTF-launched-387037 (checked 21 May 2019); "Students Loan Trust Fund Is 10 Years", GNA, 6 September 2015, https://www.ghanaweb.com/ GhanaHomePage/NewsArchive/Students-Loan-Trust-Fund-is-10-years-380126 (checked 21 February 2019); https://www.sltf.gov.gh/zakat-sadaqa-partnership-for-disbursement-repayment/ (checked 14 May 2019).

53 "Invest More Zakat, Sadaqat Fund to Build Knowledgeable Society-Veep," 3 June 2019, http://www.ghanaiantimes.com.gh/invest-more-zakat-sadaqat-fund-to-buildknowledgeable-society-veep/ (checked 12 August 2019). 
livelihood". The idea is to support widows and disabled to establish a micro-business venture "with the potential of expanding into medium and large venture". However, it seems as if the latter two schemes are not yet operating as no further information is given on the Trust Fund's homepage. ${ }^{54}$

The lack of consensus affects the outreach and impact of the Zakat and Sadaqa Trust Fund. Although it has offices in three regions (Greater Accra, Northern and Western Region), large parts of the country are not yet covered, most importantly metropolitan Kumasi and Ashanti Region with its substantial Muslim population (although I was informed in November 2019 that it seeks to open an office in Kumasi in 2020). More challenging is the question of how to address and reach out to the (growing) Muslim middle-class and present the Trust Fund as the main channel for their zakat and other donations. ${ }^{55}$ Although the Trust Fund at times receives some media coverage, regular reporting by Muslim journalists on the activities of the Trust Fund or even publishing texts on zakat is still lacking. ${ }^{56}$ Sheikh Arimiyao Shu'ab, the former CEO of the Zakat and Sadaqa Trust Fund, identified accountability and auditing as the main challenge of the Trust Fund. In his mind, the best way to remedy the lacunae is to establish an internal audit wing as well as to strengthen the existing external audit. Another problem is the lack of resources for public relations and visibility. The available funds for running offices of the Trust Fund are rather limited and restrict the number of employed officials to a bare minimum. ${ }^{57}$ Sheikh Issah in Tamale, in turn, stressed the importance of transparency to tackle the mistrust among Muslims towards the Zakat and Sadaqa Trust Fund and other zakat organizations. His suggestion is to publicize what has been collected and distributed by the Zakat and Sadaqa Trust Fund on TV each month. ${ }^{58}$

${ }^{54}$ http://ghanazakatfundonline.com (checked 31 December 2019).

${ }^{55}$ Interview with Sheikh Arimiyao Shu'ab, former CEO of the Zakat and Sadaqa Trust Fund, Accra/Legon, 7 December 2017.

56 "We Need to Form a Strong Muslim Journalists Association-Hajj Saeed Jallo," The Today's Muslim, 19 July 2018, http://thetodaysmuslim.com/discussions/we-need-toform-a-strong-muslim-journalists-association-hajj-saeed-jallo/ (checked 14 May 2019).

${ }^{57}$ Interview with Sheikh Arimiyao Shu'ab, former CEO of the Zakat and Sadaqa Trust Fund, Accra/Legon, 7 December 2017.

${ }^{58}$ Interview with Sheikh Issah, Islamic Education Unit Manager, Tamale, 9 April 2019. 


\section{The Ghana Muslim Mission Regional Zakat Fund}

A third initiative to establish a zakat fund was made by the Greater Accra Regional Branch of the Ghana Muslim Mission (GMM) in November 2014. Established in 1957, the GMM emerged as a nationalist organization and attempts to rally indigenous Ghanaian Muslims namely Ga, Fante, Asante as well as Northern Muslims into one umbrella organization and is one of the oldest (Sunni) Muslim organizations in the country. In contrast to the various national schemes, the GMM project was launched as a regional zakat fund but envisioned to develop into "the leading and credible body in Ghana". According to Nurudeen Quaye, the Greater Accra Regional Imam, the fund is projected to provide a platform for the effective collection, management and disbursement of funds to the beneficiaries of zakat. An eight-person board of trustees monitors the operations of the Regional Zakat Fund, their objective being to target "identified beneficiaries as well as implement credible governance systems that assures stakeholders it is managed prudently". Initially, its aspiration was to operate on a national level as the idea was to accumulate funds "for the development of the Muslim community in Ghana" by executing "eligible projects for the Muslim community". 59

The objectives of the GMM Greater Accra Regional Zakat Fund were ambitious. According to the (then) Chairman of the GMM Sheikh Amin Bonsu, the fund was expected to raise a minimum of GHS100,000 already by the end of 2014. The fund was expected to receive both donations in kind as well as in cash. In a public statement, Sheikh Amin Bonsu highlighted the moral imperative for Muslims to give a systematic portion of $2.5 \%$ of one's wealth each year for the benefit of the poor; zakat, he underlined, was not the same as the charitable gifts given out of kindness or generosity. The central idea of zakat, he reminded, was that it teaches Muslims' self-discipline as well as enables

\footnotetext{
59 “Ghana Muslim Mission Launches Zakat Fund," 4 November 2014, http://www. ghanaweb.com/GhanaHomePage/religion/Ghana-Muslim-Mission-launches-ZakatFund-333320 (checked 21 January 2016). See also Rabiatu Deinyo Ammah, "Ghanaian Muslims on 'Becoming Muslims' for Sustainable Development," in Religion and Sustainable Development: Ghanaian perspectives, eds. George Ossom-Batsa, Nicoletta Gati and Rabiatu Deinyo Ammah (Citta del Vaticano: Urbaniana University Press, 2018), 240-241.
} 
the empowerment of those who are poor and suffering by getting them back on their feet. ${ }^{60}$

The GMM Greater Accra Regional Zakat Fund serves as a pilot project and is monitored by a seven-member board of trustees. ${ }^{61}$ Similar initiatives have since then been launched in every region by the GMM. However, although zakat is collected annually, the generated sums remain modest. In my discussion with the GMM National Imam in 2017, Sheikh Dr. Amin Bonsu observed that zakat alone will not solve the social problems of the Muslim community in Ghana. In his mind, one should rather focus on broadening the basis of charitable donations which has become the leitmotif of the GMM. Instead of calling for a national organization, the GMM has decentralized the collection and distribution of donations to its regional headquarters. While the GMM organizes an annual national fund raising conference, regional ones are organized on an ad hoc basis. The regional headquarters, in turn, distribute the collected sums to people in need for payment of rents and school fees as well as to fund social welfare and educational projects. ${ }^{62}$

The GMM model has been rather successful in securing donations from Ghanaian Muslims and is capable of internally funding 117 schools and Colleges of Education. Sheikh Dr. Amin Bonsu noted that the GMM community is sensitized on issues of empowerment every week during the Friday prayers and in discussions afterwards. This, in turn, has created a positive atmosphere for making donations. However, the realization of its ambitious plans for establishing an Islamic university will rely on external/foreign donors. ${ }^{63}$

${ }^{60}$ Joseph Nana Yaw Cobbina, "Zakat Is the Third of the Five Pillars in Islam-Sheikh Amin Bonsu," 7 November 2014, http://newsghana.com.gh/zakat-third-five-pilars-islamsheikh-amin-bonsu (checked 19 February 2019).

61 "GMM Launches Regional Zakat Fund," GNA, 3 November 2014, http://newsghana.com.gh/gmm-launches-regional-zakat-fund/ (checked 19 February 2019).

${ }^{62}$ Interview with Sheikh Dr. Amin Bonsu, GMM National Imam, Kumasi, 10 December 2017.

${ }^{63}$ Interview with Sheikh Dr. Amin Bonsu, GMM National Imam, Kumasi, 10 December 2017. 


\section{The ASWAJ Regional Zakat Funds}

The Ahlus-Sunna Wa-Jama'a (ASWAJ) has launched at least three regional zakat funds, namely in Accra, Kumasi and Wa. Information has been collected about the activities of the ASWAJ Ashanti Region while the institutions in Accra and Wa will be the object for my forthcoming fieldwork. The leading scholars of the ASWAJ Ashanti Region made their first attempt to establish a Regional Zakat Fund in 2015. As part of the propagation for the project, the ASWAJ Ashanti Region created a homepage and published the regulations for the Zakat Fund. ${ }^{64}$ According to the regulations, the Regional Zakat Fund was structured to include a Central Zakat Fund as well as ten Zonal Zakat Funds. ${ }^{65}$ All funds accumulated in Zonal Zakat Accounts were quarterly to be transferred into the Central Zakat Fund; all moneys credited to the Fund were to be kept on non-interest bearing bank accounts. The regulations made detailed stipulations for the utilization and allocations of the annually collected assets of the Zakat Fund and granted that a maximum of $15 \%$ could be used to cover the expenses for collection, distribution and management of the fund. Half of the regional zakat budget was to be used as allowances to the needy, indigent, orphans and widows, $10 \%$ as allowances to Muslims plagued by natural disasters and were rendered homeless, and $18 \%$ for educational stipends "to needy but brilliant Muslims in Schools, Colleges, University, Polytechnic and other training institutions established or recognized by the Government". A Zonal Zakat Fund, in turn, was to use $54 \%$ of its total allocated budget for educational stipends to public madrasas and students of Deeni Madaaris (religious schools), $20 \%$ for the payment of supporting staff of Deeni Madaaris who do not receive government pay, $17 \%$ as grant to educational institutions and

\footnotetext{
${ }^{64}$ The homepage does not anymore exist (checked 21 May 2019); the regulations were still available at http://aswajashanti.org/index.php/projects-department/zakaat-fund?t$\mathrm{mpl}=\mathrm{component \& print}=1$ in 2017 when I printed them out. The document is titled: Ahl-Sunnah Wal Jama'a Ashanti Region, Regulations for Zakat Foundation, Prepared and Approved by Council of Ulamu, Office of Regional Imam, Advisory Council and Zakat and Endowment Committee, no date [2015].

${ }^{65}$ ASWAJ Ashanti Region is divided into eleven zones, namely (1) Jamasi/Agona, (2) Aboaso, (3) Offinso, (4) Barekese, (5) Abuakwa, (6) Obuasi, (7) Effiduase/Ejisu, (8) Konongo, (9) Aboabo, (10) Old Tafo and (11) Ejura, see Ahl Sunnah Wal-Jama'ah Ashanti Region, Interim Operational Report by Regional Finance Committee, May 2013. The report was available on the ASWAJ Ashanti Region homepage in 2017 and I downloaded a copy of it.
} 
to be used as stipends, $5 \%$ for health care (i.e. payment of hospital fees) and $4 \%$ for social welfare and rehabilitation of adult Muslims who do not receive any assistance from any other zakat programme or government subvention. ${ }^{66}$

However, the project ended prematurely and remained dormant for years. The main reason, Sheikh Kamil Muhammad explained, was that people refused to pay their zakat to the fund. ${ }^{67}$ Another problem was the centralized nature of the fund-the central account was supposed to receive $80 \%$ of the collected assets but local collectors rarely transferred the collected sums to the central account. ${ }^{68}$ In 2018 , however, the leadership of the ASWAJ Ashanti Region decided to call an expert on zakat from Sokoto, Nigeria, and outlined a reconstruction of the fund. As an outcome of these discussions, the two funds were fused and relaunched as the ASAWAJ Ashanti Region Zakat, Waqf and Sadaqa Fund in 2018. In comparison with the old fund, the new fund has a decentralized structure, with focus on its activities in 42 municipalities and districts in the region. ${ }^{69}$

The new decentralized structure is also reflected in the transfer of collected assets-only $20 \%$ of annually collected sums are to be transferred to the central fund's account. In April 2017, the Women's Wing of the ASWAJ Ashanti Region launched its own Zakat, Waqf and Sadaqa Fund. According to the new regulations, $60 \%$ of the collected sums are to be used by the women for their projects while $20 \%$ is earmarked to cover administrative expenses. However, the fund's coordinator Ahmed Musa admitted that the collection of zakat is still a challenge as only three persons give their zakat to the fund. Instead, most, if not all, of the existing assets of the fund are donations, i.e. sadaqa, rather than zakat collected for the new fund. ${ }^{70}$

${ }^{66}$ Ahl-Sunnah Wal Jama'a Ashanti Region, Regulations for Zakat Foundation, 1, 8-9.

${ }^{67}$ Interview with Sheikh Kamil Muhammad, Deputy Chief Imam ASWAJ Ashanti Region, Kumasi, 10 December 2017.

${ }^{68}$ Interview with Ahmad Musa, coordinator of the ASWAJ Ashanti Region Zakat, Waqf and Sadaqa Fund, Kumasi, 6 April 2019.

${ }^{69}$ Interview with Sheikh Dr. Ismail Saeed Adam, Regional Chief Imam of ASWAJ Ashanti Region, Kumasi, 5 April 2019.

${ }^{70}$ Interview with Ahmad Musa, person-in-charge of the ASWAJ Ashanti Region Zakat, Waqf and Sadaqa Fund, Kumasi, 6 April 2019. 


\section{The Muslim Ummah Development Initiative Zakat House}

The most recent proposal for a zakat fund was launched by the Muslim Ummah Development Initiative (MUDI) in 2018. The organization was designed by the Centre for Creative Leadership, Africa (CCL-Africa) and incorporated by the Coalition of Muslim Organizations-Ghana (COMOG) as a tool for the economic empowerment for Muslims in 2014. ${ }^{71}$ The driving force behind both the Centre and MUDI is the Muslim philanthropist Alhaji Alhassan Haruna, former CEO of Metro TV. The objective of MUDI is to promote the establishment of channels for halal investments, such as Islamic banking, financing and insurance in Ghana. $^{72}$

MUDI does not present itself as a new initiative for the organization for the collection and distribution of zakat in Ghana. Also, its links to COMOG are unclear. In October 2015, COMOG published an invitation for a MUDI-seminar on the empowerment of Muslim women and youth on its Facebook account. ${ }^{73}$ On my inquiries on its activities in 2017, Haji Mumuni Sulemana informed me that the initiative seems to become dormant. ${ }^{74}$ Nevertheless, the links between MUDI and COMOG were still recognized on the 2018-app of MUDI. However, information displayed on its 2019-homepage do not anymore present MUDI under the umbrella of COMOG. Instead, the organization is presented as an independent one but with the same focus on agriculture and hajj projects. Also, in contrast to the earlier outlines, the new homepage articulates an ambition to collect and distribute zakat by the organization. The vision, it seems, is to establish the MUDI Zakat House "to facilitate an institutionalized platform to enhance collection, disbursement and effective utilization of Zakat from our investors and partners". However, it is unclear if the platform has been launched. Nevertheless, the objectives of the MUDI Zakat House clearly reveal an ambition to establish an institution for the collection and distribution of zakat "from MUDI investors and partners for the wellbeing of the poor

\footnotetext{
${ }^{71}$ http://mudiappvl.herokuapp.com (checked 2 May 2019).

${ }^{72}$ Information provided by the MUDI homepage, see https://mudighana.com/ about-us/ (checked 23 April 2019).

73 "COMOG and Its Stakeholders Presents Muslim Ummah Development Initiative," 28 October 2015, https://www.facebook.com/comogghana/ (checked 2 May 2019).

${ }^{74}$ Interview with Haji Mumuni Sulemana, Legon, 1 March 2017.
} 
in our society". Echoing a modernist (and secular) discourse on poverty alleviation, its objective is "to develop and implement economic empowerment for women in the deprived communities and provide scholarships to brilliant but needy students". ${ }^{75}$ However, as its objectives are framed through the lenses of zakat, the target group are Muslim communities in Ghana.

\section{Many Local, a Few Regional or One National Zakat Fund?}

Information about the various attempts to institutionalize the collection and distribution of zakat in Ghana has generated mixed comments on social media. Some Muslims are full of praise of these efforts, others criticize them for misusing Islam. Although the negative comments on online platforms such as GhanaWeb are not representative, they still reflect some of the criticism - and misunderstandings - of the ways zakat is collected in non-Muslim secular states. The fundamental issue is the question of who has the mandate to collect and distribute. While Muslim scholars generally are in favour of an institutionalization of zakat, be it on a local, regional or national level, the negative online comments on such initiatives as well as the answers of Muslim scholars that I interviewed indicate that "ordinary" Muslims are not. Instead, it seems as if the traditional way of giving one's zakat directly to the poor and needy is preferred.

Some commentators claim that zakat should only be collected by the imams, not by organizations such as the Ghana Muslim Mission or initiatives like the Zakat and Sadaqa Trust Fund. ${ }^{76}$ One Muhammed Suraj Sulley Jawando, in turn, commenting an editorial on GhanaWeb from New York in February 2010, vehemently rejected the idea that the Zongo communities constitute the poorest strata in Ghanaian society and the Zongos to be synonymous with indiscipline, poverty and insanitation. First, he argued, Zongos constitutes multi-ethnic, multi-cultural and multi-religious communities in contemporary Ghanaian urban landscape. Second, he pointed out, walking around in Accra one locates the most miserable sanitary conditions in other neighbourhoods than the Zongo

\footnotetext{
75 "Mudi Zakat House," https://mudighana.com/mudi-structure/zakat-house (checked 23 April 2019).

76 https: / / www.ghanaweb.com/GhanaHomePage/religion/artikel. php? ID $=333320 \&$ comment $=11034428($ checked 21 May 2019).
} 
communities of Nima, New Town or Sabon Zongo. Third, he warned the Zongo, i.e. Muslim communities to rely on zakat as it constituted in his mind a negative social welfare system: "Proper accountability and disbursement is a socialist mentality that would make the Zongo people dependent on Zakat. Have you seen what the welfare checks and benefits has turned most Spanish and African-American communities in the USA? They do not work nor go to school, knowing that the welfare money will arrive at the end of the week or the month". ${ }^{77}$ Of the almost 100 comments to his article, only one discussed his rather neoliberal if not libertarian rejection of an (yet to be established) Islamic social welfare system in Ghana. "Zakat is not a socialist system', writes Ibrahim Mamoun, "but a social system encouraging growth by spreading wealth $[\ldots] "{ }^{78}$

Zakat is identified by Muslim scholars as "the Muslim solution for the eradication of misery and poverty" and a tool to facilitate the social and economic development of Muslim communities. Many of them have observed a move from the traditional payment of zakat in kind to payment in cash during the last two decades. ${ }^{79}$ However, critical voices address its haphazard and random distribution in Ghana and claim that does not meet its aims and objective at all. "Some of the rich do not give zakat and when they do, they distribute it only in small portions", noted Sheikh Jamal Deen Omar Muhammad and added that only $1 \%$ give zakat to the imams. He further recognized the fact that the aim and objective of zakat are not fulfilled as it is too unevenly distributed. ${ }^{80}$ Sheikh Issah in Tamale, in turn, identified the lack of leadership, consensus and cooperation among the Muslims in Ghana as the root causes for the failure of institutionalizing zakat. ${ }^{81}$ Sheikh Abdul Mumin Haruna, Ashanti Regional Chief Imam, as many other scholars,

\footnotetext{
${ }^{77}$ Muhammed Suraj Sulley Jawardo, "Re: Why So Much Poverty in Zongos?," 15 May 2010, https://www.ghanaweb.com/GhanaHomePage/features/Re-Why-So-Much-Povertyin-Zongos-181957 (checked 21 May 2019).

78 https: / / www.ghanaweb.com/GhanaHomePage/features / artikel. php? $\mathrm{ID}=181957 \&$ comment $=5731737($ checked 21 May 2019).

${ }^{79}$ Interview with Sheikh Jamal Deen Omar Muhammad, Imam at Tamale Central Mosque and President of Aris Social Center, Tamale, 10 April 2019; Interview with Sheikh Saeed Abubakar Zakaria, head of the Anbariya Sunni Community, Tamale, 9 April 2019.

${ }^{80}$ Interview with Sheikh Jamal Deen Omar Muhammad, Imam at Tamale Central Mosque and President of Aris Social Center, Tamale, 10 April 2019.

${ }^{81}$ Interview with Sheikh Issah, Islamic Education Unit Manager, Tamale, 9 April 2019.
} 
highlighted the need to focus on the impact of distributing zakatshould it be parcelled out in small portions and target as many recipients as possible or should a larger sum be given to one person? The rationale behind the latter argument is that the former way of distributing zakat will give a poor person food for one day while the latter way provides the tool for employment and a way out of poverty. ${ }^{82}$ Some scholars even desire to "open up" the objectives and categories of recipients of zakat and argue that it should be given to a few women instead of many (male) beggars and poor persons as "women are better in using it in a fruitful way", i.e. use zakat as a means for structural changes in one's life. ${ }^{83}$ The challenge, however, is that Muslim scholars and imams are well aware of the fact that the ideals and practice of zakat rarely correlate in Ghana, and most scholars would agree with Sheikh Anas Tawfiq in Kumasi that zakat as yet has had no impact on social development of the Muslim community. ${ }^{84}$

Not surprisingly, therefore, different visions and plans for zakat funds have been articulated by Muslim scholars and imams. According to Sheikh Osman Bawa Orlando, it has been difficult for ordinary Muslims, and many imams as well, to grasp the benefit of a national zakat fund. The traditional way is preferred by both rich businessmen and their clerics as the cleric will instruct to whom zakat is to be given. In his mind, the institutionalization of the collection and distribution of zakat needs a uniform and recognized committee but the lack of consensus is a hindrance for its realization. ${ }^{85}$ Mallam Aminu Bamba referred to his disappointing experience of soliciting funds from the community in Ejura: Local Muslims disapproved to pay zakat for the upkeep of his Primary and Junior Secondary School. ${ }^{86}$ Sheikh Jamal Deen Omar Mohammed, in turn, noted that rich people do not support the idea of establishing a zakat fund as it

\footnotetext{
${ }^{82}$ Interview with Ashanti Regional Chief Imam Sheikh Abdul Mumin Haruna, Kumasi, 15 September 2019.

${ }^{83}$ Interview with Muhammed Al-Mahaman, HOD Arabic and Islamic Studies of Al-Faruq College of Education, Wenchi, Brong Ahafo, and advisor at Sakafiya mosque, Kumasi, Kumasi, 15 September 2019.

${ }^{84}$ Interview with Sheikh Anas Tawfiq Ibrahim al-Bakri, Imam of the Darul-Hadith Mosque and Educational Complex, Kumasi, 12 December 2017.

${ }^{85}$ Interview with Sheikh Osman Bawa Orlando, Kumasi, 12 December 2017.

${ }^{86}$ Interview with Mallam Aminu Bamba, Ejura, 4 April 2019.
} 
goes against their own interests. ${ }^{87} \mathrm{~A}$ similar lamentation was presented by Sheikh Yusufiyya: Zakat is not understood by Muslims and the giver makes his own decisions to whom zakat is given. Sheikh Yusufiyya himself is in favour for the establishment of one national zakat fund. His vision is a national, transparent and public institution to which every Muslim can apply to when in need, lists its donors and publishes its accounts. ${ }^{88}$

The Council of Imams and Ulama in Kumasi, in turn, has been commenting upon the call of the Ashanti Regional Chief Imam to establish a regional zakat fund. ${ }^{89}$ However, although the issue has been on the agenda for several years, a positive decision has not been achieved as the ulama (Muslim scholars) has not (yet) reached any consensus on this issue. ${ }^{90} \mathrm{~A}$ similar position concerning the necessity to establish regional zakat funds is also taken by Sheikh Abdul Wadud. His opinion strongly reflects the position of the leadership of the Tijaniyya Muslims Movement of Ghana, namely to mobilize resources for education and educational infrastructure on a regional level through zakat. Nevertheless, he noted in the same vein that although the Tijani scholars have been propagating for this in their sermons for many years if not decades, the members have not been eager to follow their proposition. ${ }^{91}$

Some activists, such as the online community Zongo Republic, advocate a local approach. In their mind, the Zongo mosques should be put in the centre for all matters of development in the Zongo communities. To meet this end, the Zongo mosques should create a development fund for pursuing social projects. "In other words there is a development council, but this council has to meet and tell the mosque their plans and progress regularly, as opposed to holding events in different spaces outside the mosque". ${ }^{92}$ This idea correlates to arguments by some scholars

\footnotetext{
${ }^{87}$ Interview with Sheikh Jamal Deen Omar Muhammad, Director of Aris Social Center and Imam at Tamale Central Mosque, Tamale, 10 April 2019.

${ }^{88}$ Interview with Sheikh Yusufiyya, Kumasi, 12 December 2017.

${ }^{89}$ Interview with Ustaz Ahmed Said, Secretary of the Council of Imams and Ulama in Kumasi, Kumasi, 27 February 2017.

${ }^{90}$ Interview with Sheikh Zakariya Abdur-Rahman, Deputy Chief Imam Ashanti Region, Kumasi, 11 December 2017.

${ }^{91}$ Interview with Sheikh Abdul Wadud, Zameen (President) of the Tijjaniya Muslims Movement of Ghana, Kumasi, 5 April 2019.

${ }^{92}$ (Zongo Republic), "Redefining the Zongo Mosque", 8 March 2019, https://zongorepublic.com/redefining-the-zongo-mosque/ (checked 25 March 2019).
} 
and imams for the rationale to establish local, mosque-centred bayt almals or zakat funds. ${ }^{93}$

Similar negative opinions about the introduction of a national zakat fund are shared by Sheikh Kamil Muhammad, Deputy Chief Imam ASWAJ Ashanti Region. Commenting on the disappointing outcome of the 2015 initiative of launching the ASWAJ Regional Zakat Funds, Sheikh Kamil Muhammad admitted that few Muslims wanted to participate due to a lack of trust in the collectors and fear of embezzlement of collected funds. Despite of the disappointing outcome of the initiative, he stressed the need for a modernization of zakat. The solution, in his mind, was to focus on local, communal-based initiatives rather than a single national one. ${ }^{94}$

Other scholars, such as Mallam Aminu Bamba or Haji Mumuni Sulemana, are in favour of a national zakat fund. ${ }^{95}$ Sheikh Ismail Saeed Adam, ASWAJ Regional Imam in Ashanti Region, also pushes for the establishment of a national zakat fund. In his mind, a national fund could bridge the differences of the various (Sunni) Muslim sects in Ghana and could pave the way for mutual respect and tolerance among the Muslims. He envisions the fund to be an institution open for all Muslims, its central role being to evaluate the applications and to publish lists of donors for reason of transparency. However, in the same vein he admitted that not all scholars share his vision. ${ }^{96}$ Sheikh Osman Bawa Orlando, too, addresses both the positive aspects of a national fund and the lack of consensus among the scholars about the issue. However, the biggest hurdle for establishment of a national zakat fund is in his mind the sceptical if not negative attitude of lay Muslims. ${ }^{97}$

The above outline of the various visions of a zakat fund seems to indicate that the discussion has entered a cul-de-sac. Although there

\footnotetext{
${ }^{93}$ Interview with Sheikh Jamal Deen Omar Muhammad, Director of Aris Social Center and Imam at Tamale Central Mosque, Tamale, 10 April 2019; interview with Sheikh Abdulsalam Ahmed, Regional Chief Imam Northern Region, Tamale, 10 April 2019.

${ }^{94}$ Interview with Sheikh Kamil Muhammad, Deputy Chief Imam ASWAJ Ashanti Region, Kumasi, 10 December 2017.

${ }^{95}$ Interview with Mallam Aminu Bamba, Ejura, 4 April 2019; interview with Haji Mumuni Sulemana, Accra/Legon, 12 September 2018.

${ }^{96}$ Interview with Sheikh Dr. Ismail Saeed Adam, Regional Chief Imam of ASWAJ Ashanti Region, Kumasi, 12 December 2017.

${ }^{97}$ Interview with Sheikh Osman Bawa Orlando, Kumasi, 12 December 2017.
} 
have been several attempts to establish either nationwide or regional institutions, the vision of one national zakat fund is as far away as it was two decades ago. However, a new generation of scholars has presented interesting openings for a compromise that would combine the various earlier approaches on the issue. One is the idea of Sheikh Issah in Tamale who strongly recommended to include the rich and wealthy in the discussion. "Collect the wealthy in society and organize a workshop with them", integrate them in the planning process and make them stakeholders in the project. He further proposed that the process should start at the district level, i.e. the establishment of district zakat funds who would be charged to collecting zakat. Regional zakat funds would receive one-fourth of the collected sums from each district funds whereas the national zakat fund, in turn, would receive one-fourth of the assets of regional funds. Guidelines and constitutions are to be drawn for all three levels and all levels were to have registers for contributors and beneficiaries. ${ }^{98}$ Sheikh Amin Bamba has articulated a similar idea. In his vision, the national zakat fund is a decentralized institution that operates on regional and district level. Institutionally, it is to be one fund, directed and coordinated on the national level. ${ }^{99}$ Their vision could, in turn, be combined with the proposal of Sheikh Abdul Majeed and Sheikh Abdul Fatah to engage the wealthy on a communal level and form a strong organization for the local mobilization of zakat and sadaqa. ${ }^{100}$

\section{BIBLIOGRAPHY}

Altaf, Anika. Perceptions and Reflections of Islamic Development Initiatives in Northern Ghana. Amsterdam: PADEV, 2010.

Ammah, Rabiatu. "Islam and Poverty Reduction Strategies in the Ghanaian Muslim Community." Ghana Bulletin of Theology 2 (2007): 3-20.

Ammah, Rabiatu Deinyo. "Ghanaian Muslims on 'Becoming Muslims' for

Sustainable Development." In Religion and Sustainable Development: Ghanaian perspectives, eds. George Ossom-Batsa, Nicoletta Gati and Rabiatu Deinyo Ammah, 227-242. Citta del Vaticano: Urbaniana University Press, 2018.

\footnotetext{
${ }^{98}$ Interview with Sheikh Issah, Islamic Education Unit Manager, Tamale, 9 April 2019.

${ }^{99}$ Interview with Sheikh Amin Bamba Imam, Tamale, 10 April 2019.

${ }^{100}$ Interview with Sheikh Majeed, Secretary of Imam Dawah Organisation, and Sheikh Abdul Fatah, member of Imam Dawah Organisation, Tamale, 10 April 2019.
} 
Balogun, K.A. and A.A. Abdussalam. "Arguments and Counter-Arguments: A Critical Analysis of the Ahlus-Sunnah and Tijâniyyah Brotherhood Dispute in Ghana." International Journal of Humanities and Social Science Invention 4, no. 3 (2015): 1-11.

Dumbe, Yunus. Islamic Revivalism in Contemporary Ghana. Huddinge: Södertörn University, 2013.

Dumbe, Yunus. "Islamic Polarisation and the Politics of Exclusion in Ghana: Tijaniyya and Salafist Struggles over Muslim Orthodoxy." Islamic Africa 10 (2019): 153-180.

Enabling Environment of Philantbropy in Ghana. Accra: SDG Philanthropy Platform, United Nations Development Programme, 2017.

Hanson, John H. The Abmadiyya in the Gold Coast: Muslim Cosmopolitans in the British Empire. Bloomington: Indiana University Press, 2017.

Iddrisu, Abdulai. Contesting Islam in Africa. Homegrown Wabhabism and Muslim Identity in Northern Ghana, 1920-2010. Durham, NC: Carolina Academic Press, 2013.

Kobo, Ousman Murzik. "Shifting Trajectories of Salafi/Ahl-Sunna Reformism in Ghana." Islamic Africa 6, no. 1-2 (2015): 60-81.

Kobo, Ousman Murzik. "Islamic Institutions of Higher Learning in Ghana: The Case of the Islamic University College." In Muslim Institutions of Higher Education in Postcolonial Africa, eds. Mbaye Lo and Muhammed Haron, 179-191. New York: Palgrave Macmillan, 2016.

Kumi, Emmanuel. "Diversify or Die? The Response of Ghanaian Non-Governmental Development Organisations (NGDOs) to a Chaning Aid Landscape." PhD thesis, University of Bath, 2017.

Kumi, Emmanuel. "Aid reduction and NDGOs' Quest for Sustainability in Ghana: Can Philanthropic Institutions Serve as Alternative Resource Mobilisation Routes?" Voluntas 30 (2019): 1332-1347.

Muhammed, Mahmud Mukhtar and Umar Wahab Sina. "Faith in National Development: A Review of the Activities of the Istiqaama Muslim Organisation of Ghana.” Paper presented at 3rd International Conference on Religion and National Development 6th-7th September 2018, Department of Religious Studies, Kwame Nkrumah University of Science and Technology (KNUST), Ghana.

Skinner, David E. "Da'wa and Politics in West Africa: Muslim Jama'at and Non-Governmental Organisations in Ghana, Sierra Leone and The Gambia." In Development and Politics from Below: Exploring Religious Spaces in the African State, eds. Barbara Bompai and Maria Frahm-Arp, 99-130. London: Palgrave MacMillan, 2010.

Weiss, Holger. "Reorganising Social Welfare Among Muslims-Islamic Voluntarism and Other Forms of Communal Support in Northern Ghana." Journal of Religion in Africa 32, no. 1 (2002): 83-109. 
Weiss, Holger. Begging and Almsgiving in Ghana: Muslim Positions Towards Poverty and Distress. Uppsala: Nordiska Afrikainstitutet, 2007.

Weiss, Holger. Between Accommodation and Revivalism: Muslims, the State and Society in Ghana from the Precolonial to the Postcolonial Era. Helsinki: Finnish Oriental Society, 2008.

World Bank. Ghana-Performance and Learning Review of the Country Partnership Strategy for the Period FY13-FY18. Washington, DC: World Bank Group, 2016.

Open Access This chapter is licensed under the terms of the Creative Commons Attribution 4.0 International License (http://creativecommons.org/licenses/ by $/ 4.0 /$ ), which permits use, sharing, adaptation, distribution and reproduction in any medium or format, as long as you give appropriate credit to the original author(s) and the source, provide a link to the Creative Commons licence and indicate if changes were made.

The images or other third party material in this chapter are included in the chapter's Creative Commons licence, unless indicated otherwise in a credit line to the material. If material is not included in the chapter's Creative Commons licence and your intended use is not permitted by statutory regulation or exceeds the permitted use, you will need to obtain permission directly from the copyright holder.

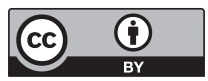

